\title{
Prednisolone and salbutamol in the hospital treatment of acute asthma
}

\author{
Gary J Connett, Catherine Warde, Edwina Wooler, Warren Lenney
}

\begin{abstract}
The use of oral prednisolone $(2 \mathrm{mg} / \mathrm{kg})$ to treat children admitted to hospital with acute asthma was assessed in a placebo controlled study. Children were further randomised to receive either $0.15 \mathrm{mg} / \mathrm{kg}$ salbutamol every 30 minutes for the first three hours of admission, or $5 \mathrm{mg}$ salbutamol every one to four hours as needed. Treatment was double blind and the assessor was unaware of the nebuliser regimen given. Children were examined before and after treatment with salbutamol on arrival and reassessed four hours after admission. Seventy children completed the study. Seventeen $(46 \%)$ of 37 children receiving prednisolone and six $(9 \%)$ of 33 receiving placebo were fit for discharge after four hours of treatment. There was no significant difference between the two nebuliser regimens. Clinical parameters indicative of asthma severity were improved in all groups. Between group comparisons at reassessment showed higher peak flows in those receiving prednisolone and nebulisers every 30 minutes but differences were not significant for other parameters. Objective parameters indicating steroid efficacy over placebo were minimal. Despite this, those receiving prednisolone were more readily identifiable as being fit for discharge within four hours of treatment. (Arch Dis Child 1994; 70: 170-173)
\end{abstract}

Systemic corticosteroids are often prescribed for the treatment of acute asthma. Although most paediatricians perceive these drugs as beneficial, the reported studies attempting to verify this have produced conflicting data. The inconsistencies between studies have been attributed to differences in study populations. ${ }^{1}$ It has been suggested that many of the negative studies include large numbers of patients with asthma improving spontaneously and so the benefits from additional steroid usage are not apparent. This hypothesis is contradicted by several good studies providing evidence for the benefit of steroids in the treatment of asthma exacerbations at home in children ${ }^{23}$ and adults. ${ }^{4-6}$ It is in the more severe cases requiring admission to hospital that the evidence is less consistent. Although some studies have suggested that steroids are beneficial in this context, ${ }^{78}$ there are several showing minimal or no benefit. ${ }^{9-14}$
Other studies in acute asthma have sought to optimise $\beta_{2}$ agonist treatment. ${ }^{15-17}$ Results suggest that high dose, frequent nebulisations, exceeding current licensing recommendations, are safe and more effective than less intensive regimens. It might be that the conflicting results from inpatient studies of steroid usage are due to differences in the extent to which concomitant bronchodilator treatment approaches the optimum dose.

Studies showing steroids to be of benefit have reported a wide timescale for the onset of clinical response. The effects of corticosteroids that are likely to benefit children with acute asthma are most commonly attributed to changes in protein synthesis mediated by RNA transcription. Although this might imply that effects would not be apparent until some time after initiating treatment, some studies have shown improvements within three to four hours. 48

This study reassesses the early effects of a single dose of prednisolone in the treatment of acute asthma. ${ }^{7}$ The benefits of prednisolone over placebo were assessed with two different nebuliser regimens: our own practice of giving $5 \mathrm{mg}$ salbutamol every one to four hours as thought necessary by nursing staff and $0 \cdot 15$ $\mathrm{mg} / \mathrm{kg}$ salbutamol every 30 minutes for the first three hours of admission. (This latter regimen approximated to the maximum dose schedule used routinely that we were aware of when planning this study. ${ }^{17}$ ) Responses to treatment were assessed four hours after starting treatment. The study was designed to determine whether the benefits of steroids could be identified when nebuliser treatment was intensified with these alternative regimens and to find out how the subsequent need for inpatient treatment was affected.

\section{Patients and methods}

The study was conducted at the Royal Alexandra Hospital for Sick Children in Brighton. The hospital admits 500-600 children annually with acute asthma of whom two thirds are self referred. Over a four month period (October 1990-January 1991) children aged over 18 months with acute asthma were considered for entry into the study depending on the availability of a single observer (GJC) to see each child within 30 minutes of arrival. Each child was assessed before and 10 minutes after $5 \mathrm{mg}$ salbutamol $(1 \mathrm{ml}$ respirator solution diluted in $2 \mathrm{ml}$ normal saline) driven by oxygen at $8 \mathrm{l} /$ minute. Children requiring admission 
were considered for entry into the study. Those entered received $2 \mathrm{mg} / \mathrm{kg}$ soluble prednisolone or an identical placebo prepared by Glaxo Pharmaceuticals. Treatments were numbered by a pharmacist in random order before the start of the study. After receiving the drug by mouth children were transferred to the paediatric ward where they were randomised in blocks of 10 to receive either $5 \mathrm{mg}$ nebulised salbutamol every one to four hours as necessary or $0.15 \mathrm{mg} / \mathrm{kg}$ nebulised salbutamol (maximum $5 \mathrm{mg}$ ) every 30 minutes for three hours. Treatment by mouth was double blind and the assessor was unaware which nebuliser regimen had been given.

All children were reassessed about four hours after admission. Assessments included measurements of heart and respiratory rate, peak expiratory flow rate (PEFR) oxygen saturation, and a severity score. This was performed at least 30 minutes after each child's most recent nebuliser treatment. The best of three blows through a mini-Wright peak flow meter was recorded and expressed as a percentage of each child's documented 'best ever' PEFR (in some children this value was obtained at follow up after hospital admission). Point value saturation measurements were recorded at specified times using a Nellcor N200 meter and disposable finger transducers. Heart and respiratory rates were obtained by brachial palpation and chest auscultation over 30 seconds respectively.

The severity score assessed degree of auscultatory findings, patient distress, and respiratory effort on scales of 0 to 6 and has been described in a previous study. ${ }^{18}$ Total scores were calculated at each assessment. All of the assessments were carried out by the same doctor. After reassessment at four hours after admission, a decision was made about the need for continued admission. This was based on each child's history, physical findings, and response to inpatient treatment without using the severity score or other clinical parameters according to specific criteria.

Parents of children sent home were asked to keep a diary of coughing and wheezing using a severity scale of 0 to 3 for the two weeks after discharge and scores were compared with those from children sent home after more prolonged admissions during the study. Ethical committee approval was obtained for the study and all parents gave informed written consent.

\section{STATISTICS}

A sample size was calculated to obtain sufficient numbers to detect a difference of $15 \%$ in peak flow values expressed as a percentage of 'best ever' with $80 \%$ certainty. Peak flow data from previous admissions to our hospital were used to estimate a standard deviation of 15 , and the age range of previous admissions suggested that $40 \%$ of children entering the study would be able to provide peak flow data. Using these figures, a total of 120 children, spread evenly between the four groups, was necessary. Unfortunately, recruitment was less than anticipated because the study assessor deemed that fewer referrals required admission than in previous years when this decision had been made by a more junior member of staff. ${ }^{19}$ Between group differences in the number of children sent home were analysed by relative risk ratios expressed as the relative likelihood of discharge. Children receiving placebo plus nebulisations every one to four hours were used as a reference group (that is a relative likelihood of discharge ratio of $1: 1$ ) with which to compare the likelihood of discharge in the other three treatment groups. The effects of prednisolone over placebo and nebulised salbutamol every 30 minutes over every one to four hours in determining the relative likelihood of discharge were also calculated. This was performed by combining groups in which these treatments were the same for the respective analyses. Analysis of between and within group differences of interval scale variables was performed using two sided Student's $t$ tests after testing the data for normality using the Shapiro-Wilk test. Differences in severity scored were analysed using the Mann-Whitney $\mathrm{U}$ test. Analyses were carried out using SAS.

\section{Results}

Of 197 referrals during the study period, 158 $(80 \%)$ were assessed and 105 admitted. Twelve were excluded because they received steroids in the two weeks before the study, three were not included because of additional croupy symptoms, and two parents refused to give consent. Ten other children were excluded because symptoms were mild; they were admitted for predominantly social reasons. Of the remaining 78 children entering the study, there were eight withdrawals. One child receiving nebulisers every 30 minutes plus prednisolone and another receiving this regimen plus placebo improved

Table 1 Demographic data

\begin{tabular}{|c|c|c|c|c|}
\hline & $\begin{array}{l}\text { Prednisolonet } \\
\text { salbutamol every } \\
30 \text { minutes } \\
(n=18)\end{array}$ & $\begin{array}{l}\text { Prednisolone }+ \\
\text { salbutamol every } \\
1-4 \text { hours } \\
(n=19)\end{array}$ & $\begin{array}{l}\text { Placebo }+ \\
\text { salbutamol every } \\
30 \text { minutes } \\
(n=15)\end{array}$ & $\begin{array}{l}\text { Placebo+ } \\
\text { salbutamol every } \\
1-4 \text { hours } \\
(n=18)\end{array}$ \\
\hline $\begin{array}{l}\text { Mean (range) age (years) } \\
\text { Male:female ratio }\end{array}$ & $\begin{array}{l}4 \cdot 7(1 \cdot 6-12 \cdot 2) \\
13: 5\end{array}$ & $\begin{array}{r}4 \cdot 7(1 \cdot 8-12 \cdot 6) \\
13: 6\end{array}$ & $\begin{array}{r}5 \cdot 5(1 \cdot 5-13 \cdot 4) \\
10: 5\end{array}$ & $\begin{array}{l}4 \cdot 6(1 \cdot 5-14 \cdot 2) \\
13: 5\end{array}$ \\
\hline $\begin{array}{l}\text { No (\%) with family history of asthma } \\
\text { in parents or siblings } \\
\text { No (\%) with family history of atopy }\end{array}$ & $9(50)$ & $8(42)$ & $7(47)$ & $10(56)$ \\
\hline $\begin{array}{l}\text { in parents or siblings } \\
\text { No (\%) parental smoking } \\
\text { Mean (range) duration of attack }\end{array}$ & $\begin{array}{r}17(94) \\
8(44)\end{array}$ & $\begin{array}{l}14(74) \\
11(58)\end{array}$ & $\begin{array}{r}11(73) \\
7(47)\end{array}$ & $\begin{array}{r}14(78) \\
9(50)\end{array}$ \\
\hline $\begin{array}{l}\text { before arrival (hours) } \\
\text { Use of inhaled prophylaxis }\end{array}$ & $22(6-120)$ & $25(8-144)$ & $37(6-240)$ & $28(5-96)$ \\
\hline $\begin{array}{l}\text { cromolyn:steroids (\%) } \\
\text { No (\%) previous use of bronchodilators }\end{array}$ & $\begin{array}{l}0: 6(28) \\
16(89)\end{array}$ & $\begin{array}{l}2: 4(31) \\
17(89)\end{array}$ & $\begin{array}{l}1: 5(41) \\
14(93)\end{array}$ & $\begin{array}{l}2: 5(39) \\
17(94)\end{array}$ \\
\hline
\end{tabular}


Table 2 Outcome when reassessed at approximately four hours after admission

\begin{tabular}{lllll}
\hline Treatment & $\begin{array}{l}\text { No } \\
\text { assessed }\end{array}$ & $\begin{array}{l}\text { No (\%) } \\
\text { discharged }\end{array}$ & $\begin{array}{l}\text { Relative } \\
\text { likelihood } \\
\text { of discharge }\end{array}$ & $\begin{array}{l}95 \% \\
\text { Confidence } \\
\text { interval }\end{array}$ \\
\hline $\begin{array}{l}\text { Prednisolone+salbutamol } \\
\text { every 30 minutes }\end{array}$ & 18 & $11(61)$ & 3.67 & 1.02 to 13.14 \\
$\begin{array}{l}\text { Prednisolone+salbutamol } \\
\text { every 1-4 hours }\end{array}$ & 19 & $6(32)$ & 1.89 & 0.47 to 7.58 \\
$\begin{array}{l}\text { Placebo+salbutamol } \\
\text { every 30 minutes }\end{array}$ & 15 & $3(20)$ & 1.20 & 0.24 to 5.94 \\
$\begin{array}{c}\text { Placebo+salbutamol } \\
\text { every 1-4 hours }\end{array}$ & 18 & $3(17)$ & 1.00 & - \\
\hline
\end{tabular}

Table 3 Relative likelihood of discharge after prednisolone compared with placebo

\begin{tabular}{lllll}
\hline & $\begin{array}{l}\text { No } \\
\text { assessed }\end{array}$ & $\begin{array}{l}\text { No (\%) } \\
\text { discharged }\end{array}$ & $\begin{array}{l}\text { Relative } \\
\text { likelihood } \\
\text { of discharge }\end{array}$ & $\begin{array}{l}\text { 95\% } \\
\text { Confidence } \\
\text { interval }\end{array}$ \\
\hline $\begin{array}{l}\text { Prednisolone } \\
\text { Placebo }\end{array}$ & 37 & $27(46)$ & $2 \cdot 53$ & $1 \cdot 12$ to $6 \cdot 10$ \\
\hline
\end{tabular}

rapidly and did not require further nebulisers. Two children receiving placebo plus nebulisers every 30 minutes were withdrawn after vomiting back their study drug, and two further children in each of the placebo groups deteriorated and required intravenous treatment within the four hour period. This left 70 children completing the study. Table 1 shows that important covariates were well balanced between the four treatment groups.

Table 2 shows the number of children in each treatment group who could be discharged when reassessed at four hours. Children receiving prednisolone plus nebulisers every 30 minutes were significantly more likely to be sent home than the reference group. This difference was significant at the $5 \%$ level. When the data from the four groups were combined, the effect of prednisolone in increasing the number of children that could be discharged is

Table 4 Relative likelihood of discharge after salbutamol every 30 minutes compared with salbutamol every 1-4 hours

\begin{tabular}{lllll}
\hline Treatment & $\begin{array}{l}\text { No } \\
\text { assessed }\end{array}$ & $\begin{array}{l}\text { No (\%) } \\
\text { discharged }\end{array}$ & $\begin{array}{l}\text { Relative } \\
\text { likelihood } \\
\text { of discharge }\end{array}$ & \begin{tabular}{l}
$\begin{array}{l}95 \% \\
\text { Confidence } \\
\text { interval }\end{array}$ \\
\hline Salbutamol every 30 minutes
\end{tabular} \\
Salbutamol every 1-4 hours & 33 & $14(42)$ & 1.74 & 0.87 to 3.60 \\
\hline
\end{tabular}

significant with $\mathrm{p}<0.05$ (table 3 ). Suggestive benefits of the more intensive nebuliser regimen did not achieve statistical significance (table 4). There was no identifiable factor within the groups that could be used to predict which children would respond to treatment at presentation.

Table 5 gives the clinical assessments before and after initial nebulisation and at reassessment at four hours. Asthma severity was comparable in all four groups at presentation using the variables listed, and there were similar responses to the initial nebuliser. Forty one per cent of children provided peak flow data. Increases in peak flow between arrival and reassessment were significant $(p<0.05)$ in all groups except placebo plus nebulisers every one to four hours $(p=0 \cdot 06)$. Between group comparisons at reassessment showed that the PEFR was significantly higher in the prednisolone plus nebulisers every 30 minutes group compared with any other group. Oxygen saturations tended to improve and differences between values at arrival and reassessment were significant $(p<0.05)$ in all except the prednisolone plus nebuliser every one to four hours group. There was no difference between groups at reassessment. Total severity scores improved significantly in all groups $(p<0.01)$ and there was a trend towards lower scores in children receiving more intensive regimens at reassessment. There was no significant change in heart and respiratory rates throughout the study period, though there was a trend towards decreasing tachypnoea in all four groups.

Table 6 gives the side effects considered attributable to asthma treatment. Tremor and hyperactivity were more commonly reported in those children receiving the more intensive nebuliser regimen but symptoms were mild and self limiting in most instances. Vomiting was more a feature of disease severity than any particular treatment group. Diary cards were given to the parents of the 23 children sent home. These were returned by all except three from children receiving prednisolone plus nebulisers every 30 minutes and one receiving prednisolone plus nebulisers every one to four hours. Mean scores for cough and wheeze in

Table 5 Clinical assessments

\begin{tabular}{|c|c|c|c|}
\hline Clinical parameter & On arrival & $\begin{array}{l}\text { After } \\
\text { nebulisation }\end{array}$ & $\begin{array}{l}\text { Reassessment } \\
\text { after treatment }\end{array}$ \\
\hline \multicolumn{4}{|l|}{ Mean (SE) percentage of 'best ever' PEFR` } \\
\hline Prednisolone + salbutamol every 30 minutes (9) & $29 \cdot 6(5 \cdot 4)$ & $44 \cdot 3(4 \cdot 4)$ & $74 \cdot 3(4 \cdot 0)$ \\
\hline Prednisolone + salbutamol 1-4 hours $(7)^{\star}$ & $26 \cdot 0(5 \cdot 3)$ & $41 \cdot 0(4 \cdot 8)$ & $52 \cdot 8(4 \cdot 6)$ \\
\hline $\begin{array}{l}\text { Placebo+ salbutamol every } 30 \text { minutes }(7)^{\star} \\
\text { Placebo + salbutamol } 1-4 \text { hours }(8)^{\star}\end{array}$ & $28 \cdot 5(5 \cdot 1)$ & $44 \cdot 3(3 \cdot 5)$ & $48 \cdot 6(6 \cdot 3)$ \\
\hline Placebo + salbutamol 1-4 hours $(8)^{\star}$ & $30 \cdot 0(5 \cdot 6)$ & $42 \cdot 7(3 \cdot 7)$ & $44 \cdot 7(4 \cdot 8)$ \\
\hline \multicolumn{4}{|l|}{ Mean (SE) percentage oxygen saturation } \\
\hline Prednisolone + salbutamol every 30 minutes & $93.5(0.59)$ & $93.1(0.35)$ & $95 \cdot 3(0 \cdot 38)$ \\
\hline Prednisolone + salbutamol 1-4 hours & $93.7(0.62)$ & $93.4(0.78)$ & $94 \cdot 5(0 \cdot 62)$ \\
\hline Placebo+salbutamol every 30 minutes & $92 \cdot 6(0.72)$ & $93 \cdot 2(0 \cdot 72)$ & $94 \cdot 7(0 \cdot 62)$ \\
\hline Placebo+salbutamol 1-4 hours & $92 \cdot 8(0 \cdot 85)$ & $93.4(0.80)$ & $95 \cdot 0(0 \cdot 61)$ \\
\hline \multicolumn{4}{|l|}{ Mean (SE) total severity score } \\
\hline Prednisolone + salbutamol every 30 minutes & $11 \cdot 7(0.64)$ & $8 \cdot 8(0.52)$ & $\begin{array}{l}5 \cdot 0(0 \cdot 75) \\
6.5(0.66)\end{array}$ \\
\hline Prednisolone + salbutamol $1-4$ hours & $12 \cdot 1(0 \cdot 60)$ & $9 \cdot 4(0 \cdot 48)$ & $6.5(0.66)$ \\
\hline $\begin{array}{l}\text { Placebo+salbutamol every } 30 \text { minutes } \\
\text { Placebo+salbutamol } 1-4 \text { hours }\end{array}$ & $\begin{array}{l}11 \cdot 8(0.49) \\
11 \cdot 7(0.45)\end{array}$ & $\begin{array}{l}8 \cdot 7(0 \cdot 36) \\
8 \cdot 2(0 \cdot 45)\end{array}$ & $\begin{array}{l}6.8(0.75) \\
7 \cdot 3(0.68)\end{array}$ \\
\hline \multicolumn{4}{|l|}{ Mean (SE) respiratory rate (breaths/minute) } \\
\hline Prednisolone + salbutamol every 30 minutes & $48(2 \cdot 5)$ & $45(2 \cdot 4)$ & $40(3 \cdot 3)$ \\
\hline Prednisolone + salbutamol 1-4 hours & $53(3 \cdot 1)$ & $46(2 \cdot 3)$ & $40(1 \cdot 9)$ \\
\hline Placebo + salbutamol every 30 minutes & $46(3.5)$ & $42(2.9)$ & $38(3 \cdot 1)$ \\
\hline Placebo+salbutamol $1-4$ hours & $44(2 \cdot 6)$ & $42(2 \cdot 5)$ & $40(2 \cdot 8)$ \\
\hline
\end{tabular}

${ }^{\star}$ PEFR $=$ peak expiratory flow rate; values in parentheses refer to the number of children in each group who were able to provide peak flow data. tRange $1-18$. 
Table 6 Side effects of drug treatment in the 76 children entering the study. Values are number (\%) of children

\begin{tabular}{|c|c|c|c|c|}
\hline Side effect & $\begin{array}{l}\text { Prednisolone+ } \\
\text { salbutamol } \\
\text { every } \\
30 \text { minutes }\end{array}$ & $\begin{array}{l}\text { Prednisolone+ } \\
\text { salbutamol } \\
\text { every } \\
1-4 \text { hours }\end{array}$ & $\begin{array}{l}\text { Placebo+ } \\
\text { salbutamol } \\
\text { every } \\
30 \text { minutes }\end{array}$ & $\begin{array}{l}\text { Placebo+ } \\
\text { salbutamo } \\
\text { every } \\
1-4 \text { hours }\end{array}$ \\
\hline $\begin{array}{l}\text { Tremor and hyperactivity } \\
\text { Vomiting } \\
\text { Headache }\end{array}$ & $\begin{array}{l}7(37) \\
1(5)\end{array}$ & $2(10)$ & $\begin{array}{l}5(25) \\
4(20) \\
1(5)\end{array}$ & $\begin{array}{l}2(10) \\
1(5)\end{array}$ \\
\hline
\end{tabular}

the first week after discharge were similar $(1 \cdot 60$ and 1.54 respectively) and were comparable with mean scores obtained from diary cards returned by 25 parents of children for the week after discharge from more prolonged admissions (1.76 and 1.57). There were no re-referrals within two weeks of discharge.

\section{Discussion}

The results of this study help to reconcile some of the contradictions published about steroid treatment. Most of the children studied improved with treatment after hospital admission. Children in the group receiving prednisolone and more intensive treatment with bronchodilators had significantly higher PEFRs at four hours compared with other study groups and this treatment regimen significantly increased the likelihood of discharge compared with the use of placebo and nebulisers every one to four hours. More intensive bronchodilatation alone did not improve outcome unless additional steroids were used and the 30 minute regimen placed excessive demands on nursing staff precluding its routine use.

Our main findings were that when steroids are used with high doses of bronchodilators there is little evidence for their benefit using objective measurements of asthma severity, but the subjective decision of 'fitness for discharge' significantly favours prednisolone use. These results are consistent with previously reported studies on the use of steroids to decrease the need for inpatient treatment. ${ }^{48}$ It is difficult to elucidate on what basis these studies have perceived steroid treatment as beneficial, but the use of a dichotomous variable such as discharge or continued admission reveals qualitative steroid induced changes that are difficult to quantify. The effect is present within four hours, and can still be appreciated when maximum amounts of bronchodilators are used. It is possible that steroids produce an appearance of wellbeing in children that is independent of therapeutic effects on the asthmatic airway. Although this might have influenced decisions about whether sufficient recovery has occurred to allow children to be sent home, the similarity in diary card data in these children to that from children discharged after more prolonged admissions (and who received further daily doses of prednisolone) suggests that the decisions were appropriate. This was further suggested by the absence of re-referrals.

The doses of bronchodilators given to the two study groups were fairly intensive and we were unable to determine whether objective steroid effects can be identified when the use of $\beta_{2}$ agonists is suboptimal. Studies on patients with asthma assessed as outpatients and receiv- ing considerably less bronchodilator than in hospitals suggests that this does occur. ${ }^{3-6}$

Studies of patients with severe asthma, refractory to large doses of bronchodilators by inhalation and intravenously, have also shown the additional benefit of steroids with significant changes in lung function. ${ }^{2021}$ It appears that during severe asthma attacks bronchodilatation by $\beta_{2}$ agonists is limited and the addition of steroids in this setting produces an independent quantifiable effect on lung function.

Like most inpatient studies, with more intensive bronchodilator treatment and comparable disease severity, our objective measurements of improvement after steroid treatment are minimal. ${ }^{4914}$ We have shown that despite this the beneficial effects of steroids are readily appreciable. The more immediate and quantifiable benefits of bronchodilators should not preclude steroid use. Routine steroid treatment for all asthma admissions can facilitate the safe discharge of an increased number of children within a short period of treatment.

Dr Gary Connett and Sisters Warde and Wooler are supported by the Royal Alexandra Hospital Rocking Horse Appeal.

1 Harris JB, Weinberger MM, Nassif E, Smith G, Milavetz G, Stillerman A. Early intervention with short courses of prednisolone to prevent progression of asthma in ambulatory patients incompletely responsive to bronchodilators. f Pediatr 1987; 110: 627-33.

2 Shapiro G, Furukawa CT, Pierson WE, Gardinier R Bierman CW. Double-blind evaluation of methylprednisolone versus placebo for acute asthma episodes. Pediatrics 1983; 71: 510-4.

3 Deshpande A, McKenzie SA. Short courses of steroids in home treatment of children with acute asthma. BMF 1986; 293: 169-71

4 Littenburg B, Gluck EH. A controlled trial of methylprednisolone in the emergency treatment of acute asthma. $N$ Engl ₹ Med 1986; 314: 150-2.

5 Fiel SB, Swartz MA, Glanz K, Francis ME. Efficacy of shortterm corticosteroid therapy in out-patient treat-ment of acute bronchial asthma. Am f Med 1983; 75: 259-62.

6 Chapman KR, Verbeek PR, White JG, Rebuck AS. Effect of a short course of prednisolone in the prevention of early relapse after the emergency room treatment of acute asthma. N Engl F Med 1991; 324: 788-94.

7 Storr J, Barry W, Barrell E, Lenney W, Hatcher G. Effect of a single dose of prednisolone in acute childhood asthma. a single dose of prednisot 1987 ; i: 879-82.

$8 \mathrm{Tal}$ A, Levy N, Gearman JE. Methylprednisolone therapy for acute asthma in infants and toddlers: a controlled clinical trial. Pediatrics 1990; 86: 350-6.

9 Kattan M, Gurwitz D, Levison H. Corticosteroids in status asthmaticus. Pediatrics 1980; 96: 596-9.

10 McFadden ER, Kisser R, de Groot WJ, Holmes B, Kiker R Viser G. A controlled study of the effects of a single dose of hydrocortisone on the resolution of acute attacks of asthma. Am 7 Med 1976; 60: 52-9.

11 Pierson WE, Bierman CW, Kelly VC. A double-blind of corticosteroid therapy in status asthmaticus. Pediatrics $1974 ; 54: 282-8$.

12 Gleeson JGA, Loftus BG, Price JF. Placebo controlled trial of systemic corticosteroids in acute childhood asthma. of systemic corticosteroids in acute
Acta Paediatr Scand 1990; 79: 1052-8.

13 Luksza AR. Acute severe asthma treated without steroids. British fournal of Diseases of the Chest 1982; 76: 15-9.

14 Stein LM, Cole RP. Early administration of corticosteroids in emergency room treatment of acute asthma. Ann Intern Med 1990; 112: 822-7.

15 Robertson CF, Beck FSR, Levison H. Response to frequent low doses of nebulised salbutamol in acute asthma. Pediatr 1985; 106: 672-4.

16 Schuh S, Reider MJ, Canny G, et al. Nebulised albuterol in acute childhood asthma: comparison of two doses. Pediatrics 1990; 86: 509-13.

17 Schuh S, Parkin P, Rajan A, et al. High- versus low-dose, frequently administered, nebulized albuterol in children frequently administered, nebulized albuterol in child
with severe, acute asthma. Pediatrics $1989 ; 83: 513-8$.

18 Connett GJ, Lenney $W$. Use of pulse oximetry in the hospital management of acute asthma in childhood. hospital management of acute

19 Connett GJ, Warde C, Wooler E, Lenney W. Audit strategies to reduce hospital admissions for acute asthma. Arch Dis Child 1993; 69: 202-5.

20 Fanta CH, Rossing TH, McFadden ER. Glucocorticoids in acute asthma. Am $\mathcal{F}$ Med 1983; 74: 845-51.

21 Younger RE, Gerber PS, Herrod HG, Cohen RM, Crawford LV. Intravenous methylprednisolone efficacy in status asthmaticus of childhood. Pediatrics 1987; 80: 225-30. 